\title{
Katarzyna Gabalewicz
}

Oddział Onkologii Klinicznej, Dolnośląskie Centrum Onkologii we Wrocławiu

\section{Rozsiew czerniaka u 77-letniej chorej leczonej pierwotnie z powodu lentigo maligna}

\section{Dissemination of melanoma in a 77-year-old patient initially treated for lentigo maligna}

\section{Adres do korespondencji:}

Lek. Katarzyna Gabalewicz Oddział Onkologii Klinicznej Dolnośląskie Centrum Onkologii we Wrocławiu

pl. Hirszfelda 12, 53-314 Wrockaw e-mail: gabalewicz.k@dco.com.pl

DOI: $10.5603 / \mathrm{OCP} .2018 .0061$ Copyright (C) 2018 Via Medica ISSN 2450-1646

\begin{abstract}
STRESZCZENIE
Przedstawiono przypadek chorej w podeszłym wieku, u której przed kilkoma laty rozpoznano lentigo maligna, uznawaną za czerniaka in situ. Dwa lata po wycięciu zmiany na skórze pacjentka zauważyła 2-centymetrowe zgrubienie. Usunięto płat powierzchowny lewej ślinianki przyusznej z guzem. W raporcie histopatologicznym opisano przerzut melanoma malignum, a w badaniach obrazowych potwierdzono rozsiew procesu nowotworowego. Pacjentkę zakwalifikowano do leczenia pembrolizumabem. Leczenie trwało od listopada 2016 roku do 18 maja 2018 roku, było dobrze tolerowane. Z powodu progresji choroby zakończono immunoterapię i chorą zakwalifikowano do radioterapii paliatywnej.

Słowa kluczowe: lentigo maligna, czerniak, immunoterapia, pembrolizumab, efekt abskopalny, działania niepożądane immunoterapii
\end{abstract}

\begin{abstract}
This paper presents a case of an elderly female patient who was diagnosed with lentigo maligna, considered to be melanoma in situ, a few years earlier. Two years after excision of the skin lesion, the patient noticed a 2-cm thickening on her neck. The superficial lobe of the left parotid gland with the tumour was removed. The histopathological report described the metastasis of melanoma malignum, and imaging studies confirmed the neoplastic dissemination. The patient was qualified for treatment with pembrolizumab. The treatment was continued from November 2016 to May 18, 2018 and was well tolerated. Due to disease progression, immunotherapy was terminated and the patient was qualified for palliative radiotherapy.

Key words: lentigo maligna, melanoma, immunotherapy, pembrolizumab, aboscopal effect,

adverse effects of immunotherapy
\end{abstract}

\section{Wstęp}

Lentigo, czyli plama soczewicowata, uznawana za czerniaka in situ, występuje głównie na skórze eksponowanej na światło słoneczne u osób w starszym wieku i często makroskopowo bywa mylona ze zmianami łagodnymi. Do transformacji złośliwej zwykle dochodzi po kilku, kilkunastu latach. Przedstawiono przypadek 77-letniej chorej, u której po stosunkowo krótkim czasie od rozpoznania lentigo maligna stwierdzono rozsiew melanoma malignum. Pacjentkę zakwalifikowano do leczenia pembrolizumabem.

\section{Opis przypadku}

W październiku 2016 roku 71-letnia kobieta zgłosiła się do poradni chemioterapii Dolnośląskiego Centrum 
Onkologii we Wrocławiu w celu ustalenia postępowania po zabiegu usunięcia guzka okolicy ślinianki przyusznej lewej.

W przeszłości, w styczniu 2014 roku, pacjentka przeszła zabieg wycięcia zmiany skóry okolicy bocznego kąta lewego oka z przeszczepem skóry z ramienia. W raporcie histopatologicznym stwierdzono w naskórku lentigo maligna wielkości $5 \mathrm{~mm}$, pod naskórkiem bez łączności z nim naevus dermalis partim neuronaevus o wielkości 1,6 cm.

Kobieta pozostawała pod obserwacją do lipca 2016 roku, kiedy po lewej stronie szyi w okolicy ucha zauważyła około 2-centymetrowe zgrubienie. W wykonanym w lipcu 2016 roku badaniu metodą tomografii komputerowej (TK) szyi opisano guzek wielkości $2 \times 1,4 \mathrm{~cm}$ w projekcji poprzecznej (TR) i $1,8 \mathrm{~cm}$ w projekcji kraniokaudalnej (CC) modelujący zarysy ślinianki, z podejrzeniem przekraczania torebki, sięgający niemal do powierzchni skóry.

Pacjentkę zakwalifikowano wtedy do zabiegu weryfikującego i w sierpniu 2016 roku usunięto płat powierzchowny lewej ślinianki przyusznej z guzem.

W raporcie histopatologicznym opisano martwiczo zmieniony fragment ślinianki z utkaniem nowotworowym zawierającym złogi barwnika, morfologicznie i immunohistochemicznie rozpoznano przerzut melanoma malignum.

W poradni zlecono pacjentce badanie metodac pozytronowej tomografii emisyjnej (PET, positron emission tomography) z fluorodeoksyglukozą w celu zobrazowania ewentualnego innego (niż wcześniej wycięta zmiana skórna ) ogniska pierwotnego oraz przerzutów odległych. Uwidoczniono konglomerat guzków wielkości $10 \times 8 \mathrm{~mm}$ aktywnych metabolicznie w segmencie IV lewego płuca [maksymalny ustandaryzowany współczynnik wychwytu $\left(\mathrm{SUV}_{\max }\right.$, maximum standarized uptake value) 6,8 ], podwyższoną aktywność w węźle chłonnym górnego bieguna wnęki lewego płuca $\left(\mathrm{SUV}_{\max } 3,2\right)$ oraz guzek z miernie podwyższoną aktywnością metaboliczną (SUV $\left._{\max } 2,9\right)$ w skórze poniżej lewego ucha - prawdopodobnie odczyn w bliźnie pozabiegowej.

Oznaczono statusu genu $B R A F$ - w przerzucie nie stwierdzono mutacji V600E; nie udało się uzyskać do konsultacji i porównania materiału z wyciętych w 2014 roku zmian skórnych.

Pacjentka pozostawała bezobjawowa, w bardzo dobrym stanie sprawności w skali (0 wg Eastern Cooperative Oncology Group - ECOG). Nie podawała w wywiadzie istotnych obciążeń poza przebytą chorobą wrzodową żołądka i zabiegami wszczepienia protez $\mathrm{z}$ powodu zmian zwyrodnieniowych stawów biodrowych. Wyniki badań laboratoryjnych, w tym stężenie dehydrogenazy mleczanowej (LDH, lactate dehydrogenase) pozostawały $\mathrm{w}$ granicach normy.
W wykonanym w listopadzie 2016 roku badaniu TK wykluczono rozsiew do ośrodkowego układu nerwowego (OUN) i poniżej przepony, natomiast w TK klatki piersiowej zobrazowano w lewym płucu nieregularny guzek o policyklicznych zarysach $1,4 \times 0,7 \mathrm{~cm}(\mathrm{TR})$ i $0,7 \mathrm{~cm}$ (CC), pojedyncze, drobne guzki u podstawy płuc oraz podejrzany węzeł chłonny podostrogowy, który osiągał $0,9 \mathrm{~cm}$ w osi krótkiej. Opisujący radiolog sugerował, że obraz wymaga różnicowania między zmianą przerzutową a niezależnym, pierwotnym nowotworem płuca.

Wobec niechęci pacjentki do diagnostyki inwazyjnej i klinicznie prawdopodobnego rozsiewu czerniaka (potwierdzony przerzut czerniaka w wyciętym fragmencie ślinianki oraz obrazy badań PET i TK klatki piersiowej) chorą zakwalifikowano do immunoterapii pembrolizumabem w dawce $2 \mathrm{mg} / \mathrm{kg}$ masy ciała co 3 tygodnie. Od 17 listopada 2016 roku do 18 maja 2018 roku otrzymała 25 kursów z subiektywnie bardzo dobrą tolerancją.

Po 2 podaniach leku wystąpiła jawna, bezobjawowa nadczynność tarczycy [obniżone stężenie hormonu tyreotropowego (TSH, thyroid-stimulating hormone), przy podwyższonym stężeniu tyroksyny (fT4) w stopniu 1. wg Common Terminology Criteria for Adverse Events (CTCAE) v. 4.0], z powodu której konsultujący endokrynolog zalecił leczenie tiamazolem w dawce $10 \mathrm{mg}$ i propranololem $3 \times 10 \mathrm{mg}$ oraz pogłębienie diagnostyki - wykonanie oznaczeń stężeń przeciwciał przeciwko receptorowi TSH (anty-TSHR, TRAb), przeciwko tyreoperoksydazie (anty-TPO) i przeciwko tyreoglobulinie (anty-TG) oraz scyntygrafii tarczycy. Nie widział jednocześnie przeciwwskazań do dalszego podawania pembrolizumabu i pacjentka kontynuowała leczenie onkologiczne bez powikłań.

W kwietniu, podczas 8. kursu leczenia pembrolizumabem wystąpiła jawna niedoczynność tarczycy z obniżonym stężeniem fT4 poniżej normy i podwyższonym stężeniem TSH powyżej $10 \mu \mathrm{IU} / \mathrm{ml}, \mathrm{z}$ powodu której odroczono kolejne podanie leku do czasu modyfikacji leczenia endokrynologicznego (włączono substytucję hormonów tarczycy).

Następne kursy pacjentka otrzymywała w rytmie z dobrą tolerancją i akceptowalnym poziomem wyników badań laboratoryjnych. Stężenie LDH cały czas pozostawało w normie.

W pierwszym kontrolnym badaniu TK w styczniu 2017 roku stwierdzono regresję widocznej poprzednio zmiany w lewym płucu i resztkowe zagęszczenia w tej lokalizacji, nadal pojedyncze drobne guzki podopłucnowe oraz nieznacznie większe niż poprzednio węzły chłonne w obu dołach pachowych do $0,6 \mathrm{~cm}$ w osi krótkiej, ale z częściowo zatartymi zarysami wnęk i wyglądem niepozwalającym wykluczyć węzłów patologicznych — według kryteriów Response Evaluation Criteria In Solid Tumours (RECIST) v. 1.1 uzyskano odpowiedź częściową. 
Kolejne badania wskazywały na stabilizację procesu nowotworowego, w tym obrazu płuc i zmian węzłowych.

W TK wykonanej po 24 podaniu pembrolizumabu w maju 2018 roku w prawym talerzu biodrowym pojawiła się osteolityczna zmiana z miękkotkankowym naciekiem uwypuklającym się poza zarysy kości, osiągająca $2,8 \times 1,5 \mathrm{~cm}(\mathrm{TR})$ i $2,6 \mathrm{~cm}(\mathrm{CC})$, natomiast w okolicy operowanego guzka ślinianki uwidoczniono pasmo wzmocnienia kontrastowego grubości do $0,4 \mathrm{~cm}$ i około $2,7 \mathrm{~cm}$ w wymiarze przednio-tylnym (AP) - obraz mogący odpowiadać zmianie bliznowatej, ale wymagający obserwacji.

Pacjentka zgłaszała bóle okolicy biodra, poza tym pozostawała w bardzo dobrym stanie sprawności.

Z powodu progresji choroby według kryteriów RECIST zakończono leczenie pembrolizumabem.

Biorąc pod uwagę dolegliwości, charakter osteolityczny zmiany i brak cech ewidentnej progresji w innych lokalizacjach chorą zakwalifikowano do radioterapii paliatywnej fotonami 6 i $10 \mathrm{MeV}$ na obszar zmiany w obrębie prawej kości biodrowej z marginesem otaczających tkanek do Dc $=20$ Gy/5 f, Df $=4$ Gy, którą zrealizowano w lipcu 2018 roku.

Po radioterapii zaplanowano badania kontrolne i ewentualną kwalifikację do leczenia drugiej linii.

\section{Omówienie}

U pacjentki pierwotna zmiana skórna rozpoznana była jako lentigo maligna, czyli plama soczewicowata, uznawana za czerniaka in situ. Występuje ona głównie u osób w starszym wieku, na skórze eksponowanej na światło słoneczne i często makroskopowo bywa mylona ze zmianami łagodnymi. Ryzyko transformacji złośliwej szacuje się na około 5-20\% [1]. Zwykle dochodzi do niej po kilku, kilkunastu latach, choć znane są przypadki szybkiej wznowy w postaci inwazyjnego czerniaka i/lub dynamiczny rozsiew choroby [2]. Po leczeniu chirurgicznym niezbędne jest poinformowanie pacjentów o konieczności obserwacji blizny i okolicznych węzłów chłonnych oraz długotrwałe ich monitorowanie, co może się przyczynić do szybszego wykrycia wznowy i zahamowania rozsiewu leczeniem miejscowym.

U przedstawionej chorej, wobec przesłanek klinicznych oraz braku zgody na weryfikację zmian w płucu, których obraz radiologiczny nie był do końca jednoznaczny, zastosowano w pierwszej linii leczenia immunoterapię pembrolizumabem, humanizowanym przeciwciałem przeciwko receptorowi programowanej śmierci komórki PD-1, uzyskując kontrolę choroby przez 18 miesięcy, nie generując istotnych toksyczności i utrzymując bardzo dobrą jakość życia.
Leczenie było subiektywnie bardzo dobrze tolerowane. Pomimo wystapienia wczesnych powikłań endokrynologicznych w postaci zaburzeń funkcji tarczycy nie dawały one objawów, były dobrze kontrolowane i nie wymagały stosowania kortykosterydów.

Ponieważ działania niepożądane immunoterapii mogą doprowadzić do sytuacji zagrażających życiu i wymagają szybkiego wdrożenia odpowiedniego postępowania, pacjentkę na wczesnym etapie skierowano do endokrynologa, który włączył się w proces leczenia chorej.

Rola endokrynologów pozostaje nadal znacząca, pomimo że onkolodzy mają obecnie coraz większe doświadczenie w stosowaniu immunoterapii i dostęp do dobrze opracowanych algorytmów postępowania w przypadku wystąpienia powikłań [3, 4]. Praktyka w interpretacji wyników dodatkowych badań laboratoryjnych i obrazowych zlecanych w celu różnicowania etiologii nadczynności lub niedoczynności gruczołów wydzielania wewnętrznego (takich jak przeciwciała, badania hormonalne, scyntygrafia jodowa lub technetowa tarczycy) [5] oraz możliwość specjalistycznego leczenia bywa często przydatna w prowadzeniu chorego na nowotwór. Niezbędna jest też długotrwała obserwacja pacjentów, gdyż niektóre z zaburzeń endokrynologicznych — choć częściej występują na wczesnym etapie leczenia - mogą się ujawnić nawet rok po zaprzestaniu terapii.

Po progresji w trakcie immunoterapii, biorąc pod uwagę charakter nowej zmiany, która pojawiła się w przebiegu choroby, zdecydowano się na zastosowanie u pacjentki paliatywnej radioterapii miejscowej. Ta według dostępnych danych potencjalnie mogłaby wspomóc uzyskanie długotrwałej odpowiedzi na leczenie poza obszarem napromienianym (w mechanizmie efektu abskopalnego) i korzystnie przełożyć się na odległe efekty leczenia [6].

\section{Piśmiennictwo}

1. Margit L., Juhász W., Marmur E.S. Reviewing challenges in the diagnosis and treatment of lentigomaligna and lentigo-maligna melanoma. Rare Cancers Ther. 2015; 3: 133-145.

2. Abdaal A., Price R.D., Durrani A.J. Rapid recurrence of lentigo maligna melanoma - A case report. JPRAS Open 2017; 13: 106-110.

3. Haanen J.B.A.G., Carbonnel F., Robert C. i wsp. Management of toxicities from immunotherapy: ESMO Clinical Practice Guidelines for diagnosis, treatment and follow-up. Ann. Oncol. 2017; 28 (supl. 4): iv119-iv142.

4. Charakterystyka Produktu Leczniczego Keytruda

5. Kottschade L., Brys A., Peikert T. i wsp. A multidisciplinary approach to toxicity management of modern immune checkpoint inhibitors in cancer therapy. Melanoma Res. 2016; 26: 469-480.

6. El Chediak AShamseddine A., Bodgi L., Obeid J.P., Geara F., Zeidan Y.H. Optimizing tumor immune response through combination of radiation and immunotherapy. Med. Oncol. 2017; 34: 165. 